\title{
FACTORS AFFECTING CREDIT SPREAD IN INDIAN DEBT MARKET
}

\author{
Praveen Gupta \\ Symbiosis Institute of Business Management Bengaluru.
}

\begin{abstract}
This paper shows that how Macro risk factors affect the credit spread in the Indian debt market. Credit spread is the difference between government bonds and corporate bonds of the same maturity. Various factors impact the spread directly and indirectly. The main focus of this paper to determine the relationship between these factors and find out which factors are explaining credit spread. This paper determines the significance linear dependency of credit spread on various factors through regression analysis. These factors are the market risk factors such as Inflation, GDP growth, and liquidity factors like the Repo rate. This paper will show that whether we are accepting the null hypothesis which states that these factors affect the credit spread or reject the hypothesis of no impact of variables on credit spread
\end{abstract}

Keywords: Credit spread, Liquidity, Market risk, inflation, Repo rate, credit rating

\section{Objective}

The purpose of this paper is to explain the Credit spread between corporate bonds and government bonds and factors that affect credit spread through regression analysis. We will examine the factors affecting the credit spread and see the significance level of these factors by applying the statistical model. Credit spread is one of the important terms in finance where we can decide the impact on the economy as well.

\section{Literature Review}

According to Davies's research on credit spread determinants, higher-risk firms are particularly vulnerable to the economic environment within a deflationary environment. High-grade bonds are alternatively the subject of a very low level of default risk. The primary concern for investors in high-grade debt is the risk of inflation since bonds generally perform poorly under inflationary conditions.

According to Chikashi Tsuji the credit rating would explain spreads, but only to a limited degree; it would also partially or completely dominate the explanatory power of illiquidity and credit-related factors due to its synthetic characteristic.

The Merton framework states that the risk-free rate has an impact on the value of the corporate bond. The overall effect of an increase in the risk-free rate is to decrease the effective costs of insurance against default on the firm's debt. So, as the risk-free rate increases, the credit spread should tighten.

The Paper was written by Anton Scholin and Flip Persson Mork who described credit spread through the autoregressive model to make a long-term simulation of credit spread of high yield and investment-grade bonds. It checked the simulation with static consistent with the historical data. The study is done on the US market. However, a study on one market does not necessarily reflect the same relation in another market. In emerging market, where the risk is high that in turn drives up the yield and spread up has a different relationship with the macro or liquidity factors compare to a developed market.

\section{Methodology}

For the quantitative analysis, Author uses multiple regression model to check the explanatory power of each variable and overall explanatory power through the value of $\mathrm{R}$ square which defines how much independent variables explains dependant variable. $\mathrm{R}$ square also states that whether the model is a good fit or not. We check the significance level of each variable just to check whether to accept or reject the hypothesis.

Null hypothesis H0 states that independent variables have an impact on dependant variable (credit spread). Ha is the alternative hypothesis which states that they don't affect the credit spread.

Independent variables: Sensex, Inflation, VIX, Repo rate, GDP growth, USDINR

Dependent variable: Credit spread

Model equation: Credit spread $(\mathrm{Y})=\mathrm{B} 0+\mathrm{B} 1 *($ Repo rate $)+$ $\mathrm{B} 2 *($ Inflation $)+\mathrm{B} 3 *(\mathrm{VIX})+\mathrm{B} 4 *(\mathrm{BSE}$ Sensex $)+\mathrm{B} 5 *(\mathrm{GDP}$ growth $)+\mathrm{B} 6 *($ USDINR $)$

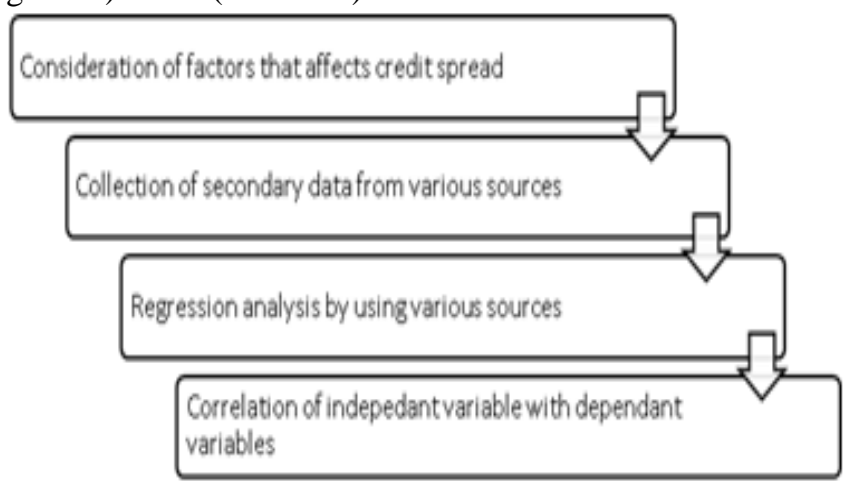


Multiple Regression: Multiple regression is the extension of linear regression and it is performed to know the relationship between more than two variables. Here, we have one dependant variable and multiple independent variables. It also tells the interrelationship/Correlation between independent variables which will be adjusted to arrive at overall correlation of the model.

Correlation: Correlation is a statistical measure that tells the relationship between two or more variable in relation to each other. It measures how one variable moves with another variable. It will be decided by indication of correlation such as positive, negative or zero correlation.

\section{The corporate bond market in India}

The corporate bond market in India remains crucial for businesses across sectors. Companies raise the money apart from the equity market (public companies) to finance the operation by issuing various securities like a bond, debenture, commercial paper, etc. Corporate bonds are issued by Public sector undertakings and private firms. These bonds are issued for a varied timeline from 1 years-15 year. These bonds carry different risk profiles from high investment grade to high yield bonds. Credit rating is given by the rating agencies that evaluate a company's creditworthiness. High investment-grade bonds (AAA) are considered to be the less risky security and are in high demand.

If investors buy bonds aggressively due to yield attractiveness or economic slowdown, Bonds demand is high, which means that the bond price will go up that in turn pushes the yield down. This is the simple relation between price and yield. Similarly, high yield bonds (Less than BBB-) fetch less demand and subsequently, low price drives up the yield for the particular bonds. This generally happens in a stressful situation where a company is struggling with stagnant cash flow.

The corporate bond market is managed by the Securities and exchange board of India (SEBI). Talking about the numbers, Indian domestic debt accounts for $67 \%$ of GDP, and out of which, Corporate bond market size is $16 \%$ of the GDP compared to the $46 \%$ in Malaysia, $73 \%$ in South Korea. These numbers state that the corporate bond market is small in India. It is because there is no easy money available in the Indian market. Banks, institutional investors side themselves not to lend money to the businesses due to the risky nature of businesses. Though, the Indian corporate bond market is growing gradually. RBI flooded the money to the banks by reducing the policy rate and introducing various new money operations (LTRO, TLTO, OMO) to encourage banks to lend money to businesses, MSMEs, etc.

\section{Dependent variable}

In this paper, Credit spread is the dependant variable. Credit spread is the difference between the government and corporate bonds of the same maturity. So, let's say we have a 10-year government bond which we call G-sec in India and we have AAA-rated 10-year corporate bond. The rate at which they are issued is called yield and yield generally defined through the credit rating of the security.

Credit spread $=R i-R g$

Where $\mathrm{Ri}$ is corporate bond yield and $\mathrm{Rg}$ is government bond yield.

Credit rating is the quantified measurement of the creditworthiness of the company. It is the evaluation of the credit risk of a company and checks whether a company that issued bonds could default or not. Suppose a company ABC issued bonds to raise the fund and the company's financials are in good health that means they can pay the coupon (periodic payment to bondholders by bond issuers) to bondholders.

Credit rating agencies analyze the creditworthiness of the companies and provide a rating $(\mathrm{AAA}, \mathrm{BBB}, \mathrm{BB}+, \mathrm{D})$ to the corporation after evaluating various parameters through a standard methodology. AAA rating is a highly secured rating and this means that companies having AAA ratings will not face any difficulty raising money and pay less yield to investors. In contrast to the AAA bonds, A company that is debt-ridden and has high financial leverage with less growth opportunity will fetch a low rating (let's say BBB-) because of their weak cash flow and lack of growth. A low rating means that the company raises money at a high cost. This high cost is the yield to the bond that they issue.

In an uncertain time like nowadays where Covid-19 has crippled businesses around the world and their cash flow has been stagnant, they are losing money due to the mute consumption. These businesses will find difficulty in raising money from lenders. So, they need to pay the high cost or extra compensation to the bondholders. These businesses might also attract low ratings due to the bad creditworthiness and yield will go up.

On the other side, Government bonds or securities are generally risk-free because they are issued by the governments and historically there is very little chance that government would default on payment so they are considered as risk-free security. Government bond yield depends on the sovereign rating of the country. Talking about the India, sovereign rating is one notch up from the junk rating (BAA3) with a negative outlook by Moody. This fetches the yield a bit higher than other stable ratings like US low yield because of their AAA rating.

This fetches one of the important points that credit rating affects the yield and that in turn affects the credit spread. Well, we will not see any kind of analysis on credit rating affecting credit spread because of one simple reason: credit rating attracts unfairness in the credit market and this might not give a better judgment on the spread. Overall, the credit rating may impact the credit spread but it is a limited impact. In this 
paper, we are too focused on the liquidity factor and Market risk factors.

Credit spread $=($ corporate bond yield - Government bond yield)

Credit spread $=(1-$ recovery rate $) *$ default probability

This paper will not explain the second formula because here we are not considering the default rate and recovery rate. This is only for information purposes.


Source: Investopedia

\section{Independent Variables}

Independent variables: GDP growth, BSE return, Inflation, the Volatility Index (VIX), Repo rate. GDP growth is the growth of the GDP number quarter on quarter. GDP data is available every quarter. BSE return is the daily return over the previous day. Inflation is the economic term that refers to the rise in the price of the goods and services of daily or common things like food, clothing, housing, etc. The consumer price index is an index that measures the average change in the price of the basket of goods and services that the consumer pays. it measures retail inflation.

The volatility index is the indicator of the market sentiment in the short term. It is a widely used indicator to measure the market risk and is constructed by the price of the Nifty option (put and call). VIX also denotes the indication by which investors expect the market to move in the next 30 days. Repo rate is the interest rate set up by the Central bank of any country at which they lend money to the Banks. It is generally called the fund rate in the US.

Repo rates affect credit spread when the repo rate is slashed to push the liquidity in the market. When the liquidity is flooded in the market, money becomes cheap, and that in turn pushes the cost or yield of the company bonds down. Government security yield too becomes low due to the cheap money available for the government. This directly means that the credit spread is narrowed due to the rate cut. Opposite also holds the relation with the spread being expanded with the increasing rate.

BSE Sensex numbers also affect the credit spread. When there is an outflow from equity, which often happens in uncertain times, investors put their money in safe-haven like Gold and debt. This means that money inflow in debt increases and drives up the demand in the bond market. When demand is high, yield drops and credit spread shrinks. Unlike it, when there is an inflow in the equity market, the credit spread is up. Credit spread is exposed to the fluctuating economic condition which we see through inflation. Inflation risk affects the credit spread. In simple words, A fall in inflation means low cash flow in the company, and this increases the credit risk of the company and further high default risk fetch high yield and then credit spread will go up.

USDINR exchange affects the credit spread. When the rupee is appreciated which means there is an inflow of FPI/FII in the debt market and that increases the value of money. This inflow means that the demand is high in the bond market and yield will go down. As the corporate yield goes down, the spread is compressed. Similarly, when there is an outflow, the spread goes up.

\section{Data collection}

Data is taken from various secondary sources including RBI, SEBI, NSE, BSE, FIMMDA, etc. GDP data is available quarterly. Inflation data is available on monthly basis on the RBI website. VIX data is extracted from Yahoo finance. BSE Sensex data is also taken from Yahoo finance. 10-year G-sec data is available on daily basis and it is taken from Investing.com. 10-year AAA corporate bond yield is also taken from various websites.

Repo rate is available periodically. The monetary policy committee (MPC) holds meets at least 4 times a year and MPC decides the rate in the meeting. Repo rate data is taken from the RBI website. USDINR data is taken from investing.com. Data is analyzed through the SPSS software that is a good statistical tool to test any kind of model.

\section{Analysis}

The regression model is run on the 6 independent variables and 1 dependant variable. By looking at the Pearson Correlation table, we can say that Sensex, the repo rate has a high correlation with the credit spread. VIX showed a weak correlation with the credit spread. If we look at the direction of correlation, there is a negative correlation of Inflation, GDP growth, VIX, Repo rate with a credit spread. There is a positive relation between Sensex and USDINR with credit spread. 


\begin{tabular}{|c|c|c|c|c|c|c|c|c|}
\hline \multicolumn{2}{|l|}{ Correhations } & Credit spread & Sensex & Inflation & $\begin{array}{l}\text { GDP } \\
\text { growth }\end{array}$ & VIX & Repo Rate & USDINR \\
\hline \multirow[t]{7}{*}{ Pearson Conelation } & Credit spread & 1.000 & & & & & & \\
\hline & Sensex & $.501^{*}$ & 1.000 & & & & & \\
\hline & Inflation & $-376 *$ & .084 & 1.000 & & & & \\
\hline & GDP growth & $-314^{*}$ & .653 & .162 & 1.000 & & & \\
\hline & VIX & $-.133^{*}$ & -.120 & -011 & -398 & 1.000 & & \\
\hline & Repo Rate & $-439 *$ & .550 & . & .762 & - .400 & 1.000 & \\
\hline & USDINR & $310^{*}$ & .433 & -.066 &. .717 & .570 & .642 & 1.000 \\
\hline \multirow[t]{7}{*}{ Sig. (1-tailed) } & Credit spread & & & & & & & \\
\hline & Sensex & .000 & & & & & & \\
\hline & Inflation & .000 & .001 & & & & & \\
\hline & GDP growth & .000 & .000 & .000 & & & & \\
\hline & VIX & .000 & .000 & .343 & .000 & & & \\
\hline & Repo Rate & .000 & .000 & .017 & .000 & .000 & & \\
\hline & USDINR & 000 & 000 & 008 & .000 & 000 & 000 & \\
\hline
\end{tabular}

Source: Regression result

*significant $<0.05$

The significance level of the model is $<0.005$ ( $95 \%$ confidence level so alpha is 5\%). We assumed that all the variables are significant at a $95 \%$ confidence level. It further means that each factor affects the credit spread as we accept the null hypothesis.

\begin{tabular}{|c|c|c|c|c|}
\hline \multicolumn{5}{|c|}{ Model Summary ${ }^{b}$} \\
\hline Model & $\mathrm{R}$ & R Square & $\begin{array}{|ll|}\text { Adjusted } & R \\
\text { Square } & \end{array}$ & $\begin{array}{l}\text { Std. Error of the } \\
\text { Estimate }\end{array}$ \\
\hline 1 & $.754^{a}$ & .569 & .567 & .235975 \\
\hline
\end{tabular}

a. Predictors: (Constant), Sensex, Inflation, VIX, Repo Rate, USDINR, GDP growth

b. Dependant: Credit spread

The model summary has an $\mathrm{R}$ square count of 0.569 which means the model is $56.9 \%$ explained by the independent variables. But due to the interrelation between these variables, we will take adjusted $\mathrm{R}$ square which excludes the impact of the interrelationship of the variables. Given that the model is $56.7 \%$ explained by these variables, it is considered a good number in regression analysis.

ANOVA $^{\mathrm{a}}$

\begin{tabular}{|ll|l|l|l|l|l|}
\hline \multicolumn{2}{|l|}{\begin{tabular}{l} 
Model \\
\hline 1
\end{tabular}} & $\begin{array}{l}\text { Rum of } \\
\text { Squares }\end{array}$ & df & $\begin{array}{l}\text { Mean } \\
\text { Square }\end{array}$ & F & Sig. \\
\hline & $\begin{array}{l}\text { n } \\
\text { Residual }\end{array}$ & 94.569 & 6 & 15.761 & 283.05 & $.000^{\mathrm{b}}$ \\
& 71.666 & 1287 & .056 & & \\
Total & 166.235 & 1293 & & & \\
\hline
\end{tabular}

a. Dependent Variable: Credit spread

b. Predictors: (Constant), USDINR, Inflation, Sensex, VIX, Repo Rate, GDP growth

In the ANOVA table, the Significance level is less than alpha (0.05) which means that we accept the null hypothesis that credit spread is affected by these variables directly and indirectly. We do not accept the alternate hypothesis which states that there is no impact of the factors on credit spread.

\begin{tabular}{|c|c|c|c|c|c|c|c|c|c|c|}
\hline \multirow[b]{2}{*}{ Model } & \multicolumn{2}{|c|}{$\begin{array}{l}\text { Unstandardized } \\
\text { Coefficients }\end{array}$} & \multirow{2}{*}{$\begin{array}{c}\text { Standardized } \\
\text { Coefficients } \\
\text { Beta }\end{array}$} & \multirow[b]{2}{*}{$t$} & \multirow[b]{2}{*}{ Sig. } & \multicolumn{3}{|c|}{ Correlations } & \multicolumn{2}{|c|}{$\begin{array}{l}\text { Collinearity } \\
\text { Statistics }\end{array}$} \\
\hline & B & $\begin{array}{l}\text { Std. } \\
\text { Error }\end{array}$ & & & & $\begin{array}{l}\text { Zero- } \\
\text { order }\end{array}$ & Partial & Part & Tolerance & VIF \\
\hline 1 (Constant) & .436 & .266 & & 1.637 & .102 & & & & & \\
\hline Sensex & $1.945 \mathrm{E}-5$ & .000 & .271 & 8.923 & .000 & .501 & .241 & .163 & .363 & 2.755 \\
\hline Inflation & -.124 & .005 & -.458 & -23.674 & .000 & .376 & .551 & -.433 & .894 & 1.118 \\
\hline $\begin{array}{l}\text { GDP } \\
\text { growth }\end{array}$ & .095 & .007 & .519 & 13.835 & .000 & -.314 & .360 & .253 & .238 & 4.194 \\
\hline VIX & -.016 & .001 & -.334 & -11.995 & .000 & -.133 & -.317 & -220 & .432 & 2.312 \\
\hline Repo Rate & -.333 & .016 & -.647 & -21.003 & .000 & -.439 & .505 & -384 & .353 & 2.829 \\
\hline USDINR & .033 & .003 & .309 & 10.165 & .000 & .310 & .273 & .186 & .363 & 2.756 \\
\hline
\end{tabular}

Final multiple linear regression equation:

Credit spread $(\mathbf{y})=0.436+0.271 *($ Sensex $)-$ $0.458 *($ Inflation $)+0.519 *($ GDP growth $)-0.334 *(\mathrm{VIX})-$ $0.647 *($ Repo rate $)+0.309 *($ USDINR $)$

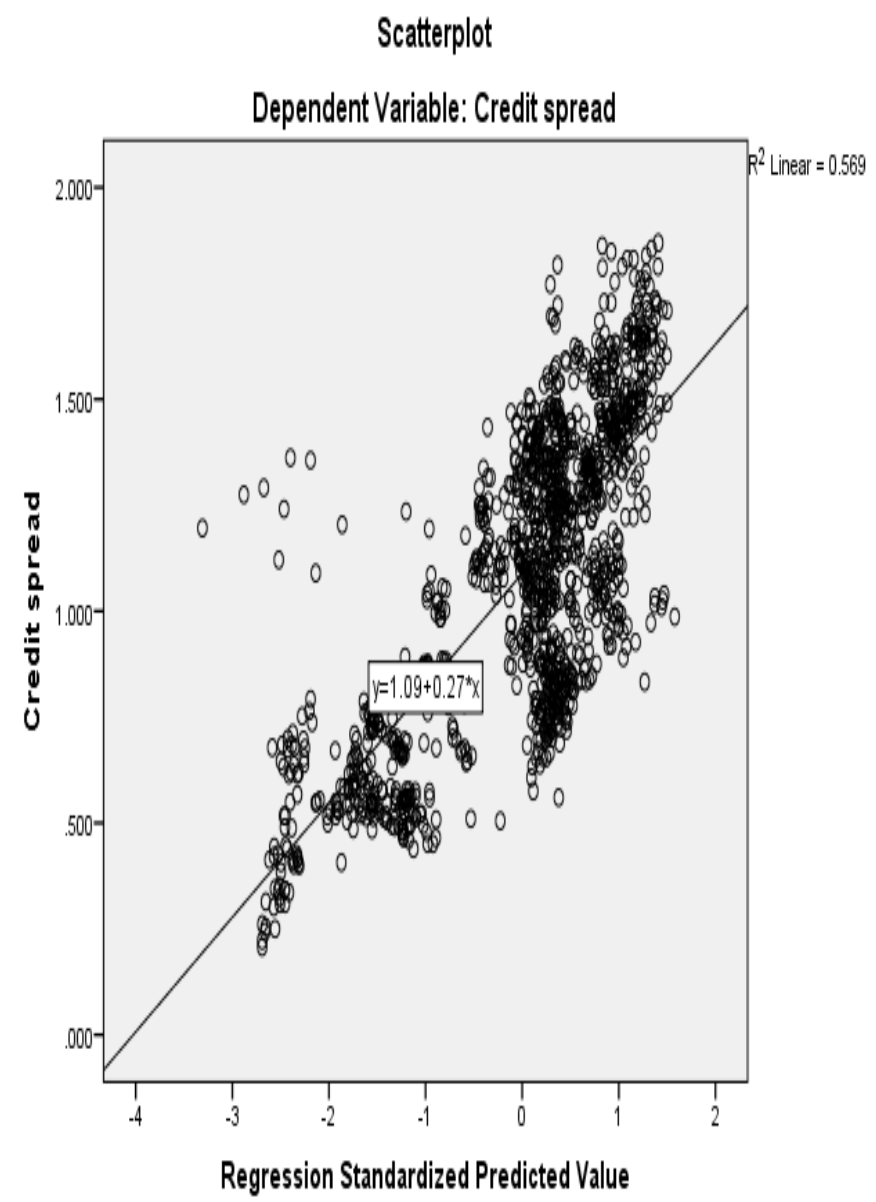

The Scatter plot diagram shows the correlation of the model how the variable data is a good fit of the model which is described by $\mathrm{R}$ square. Here $\mathrm{R}$ square value is $56.9 \%$ so we can say that the $56.9 \%$ model is approximated with the real 
data. Though it not highly fit model but it tells the clear picture of factors impacting credit spread.

\section{Limitation}

In this research paper, Factors were taken which has a direct and indirect impact on credit spread. However, there are some other factors also that can affect the credit spread directly i.e., default rate. The author did not take the credit risk factors into this paper. This paper included the market risk factors only. Also, to find the correlation and significance of the model, the Author considered regression analysis. However, there is the scope of applying an advanced level statistic model which can give more validity to the factor correlation with the credit spread. This research paper is focused only on the long-term yield which 10 Year AAA bonds spread over G-sec bonds. However, one can see the impact on the short-term spread and high yield market as well.

\section{Conclusion}

Market risk factors such as inflation, the repo rate, GDP growth, etc. affect the credit spread. If we look at the Pearson correlation, only VIX has weak relation with credit spread and this is possible because of the high volatility nature of the money market. The remaining variables have a good relationship with the credit spread, however, it is limited nature of correlation. BSE Sensex number showed a high positive correlation with the credit spread because when there is a drop in Sensex, money goes to the bond market and that further drops the yield and credit spread. By looking at the regression equation, Inflation and credit spread holds a negative correlation which means if inflation is rising, 10-yr G-sec yield will rise and narrow down the credit spread. Similarly, Repo rate depicts the -ve correlation with the spread which means that repo rate increment will push G-sec yield up and further fill the gap in spread. After looking at the equation, we can say credit spread is affected by many factors.

\section{References}

[1] Collin-Dufresn, P., Goldstein, R. S., \& Martin, J. S. (2001). The determinants of credit spread changes. The Journal of Finance, 56(6), 2177-2207.

[2] Delianedis, G., \& Geske, R. (2001). The components of corporate credit spreads: Default, recovery, tax, jumps, liquidity, and market factors.

[3] Batten, J. A., Fetherston, T. A., \& Hoontrakul, P. (2006). Factors affecting the yields of emerging market issuers: Evidence from the Asia-Pacific region. Journal of International Financial Markets, Institutions and Money, 16(1), 57-70.

[4] Liang, Y., \& Zhu, Z. (2017, June). A study on the factors affecting credit spreads of corporate bonds from the perspective of credit risk. In 2017
International Conference on Service Systems and Service Management (pp. 1-6). IEEE.

[5] Krishnamurthy, A. (2002). The bond/old-bond spread. Journal of financial Economics, 66(2-3), 463-506.

[6] Forte, S., \& Pena, J. I. (2009). Credit spreads: An empirical analysis on the informational content of stocks, bonds, and CDS. Journal of Banking \& Finance, 33(11), 2013-2025.

[7] Collin-Dufresn, P., Goldstein, R. S., \& Martin, J. S. (2001). The determinants of credit spread changes. The Journal of Finance, 56(6), 2177-2207.

[8] Avramov, D., Jostova, G., \& Philipov, A. (2007). Understanding changes in corporate credit spreads. Financial Analysts Journal, 63(2), 90-105.

[9] Bahure, V., \& Singhal, A. (2009). DETERMINANTS OF CREDIT SPREAD \& ANNUAL COUPON RATE. Liquidity Assessment Facility (LAF), 3(2), $1-14$.

[10] https://www.investopedia.com/terms/c/creditspread.a $\mathrm{sp}$

[11] http://www.financerisks.com/filedati/WP/Common_f actor/The $\% 20$ Determinants $\% 20$ of $\% 20$ Credit $\% 20 \mathrm{Sp}$ read\%20Changes.pdf

[12] Shaheen, R. (2020). Credit market conditions and impact of monetary policy in a developing economy context. International Economics and Economic Policy, 1-17.

[13] Hattori, M., Koyama, K., \& Yonetani, T. (2001). Analysis of credit spread in Japan's corporate bond market. The changing shape of fixed income markets: a collection of studies by central bank economists, BIS Papers, (5), 113-46.

[14] Allen, L., \& Saunders, A. (2002). A survey of cyclical effects in credit risk measurement models. 